\title{
ДЭЛХИЙН ФИЛОСОФИЙН өДРИЙГ ТЭМДЭГЛЭНЭ
}

ЮНЕСКО-гоос жил бүрийн арваннэгдүгээр сарын гурав дахь долоо хоногт “Дэлхийн философийн өдөр”-ийг тэмдэглэж байхаар уриалан тунхагласан байдаг. Дэлхийн Философийн өдөр нь бидэнд орчин үеийн нийгмийн өөрчлөлтийг бүтээлч шүүмжлэлт сэтгэлгээгээр авч үзэх боломж олгодог. Манай улсын хувьд “Дэлхийн философийн өдөр”-ийг бүтээлчээр өнгөрүүлдэг уламжлалтай билээ.

“Дэлхийн философийн өдөр”-ийг тохиолдуулан ШУА-ийн Философийн хүрээлэн, МУИС-ийн Философи, шашин судлалын тэнхим, ШУТИС-ийн Бизнесийн Удирдлага, хүмүүнлэгийн сургууль болон Эмнести Интернэшнл хүний эрхийн байгууллагаас хамтран философи сонирхон судалж буй их, дээд сургуулийн философийн магистрант, докторант оюутнуудын дунд Философийн IX удаагийн улсын олимпиадыг “Философи, хүний эрхийн уулзварт: Цахим эрх чөлөө" сэдвийн хүрээнд энэ оны 12 дугаар сарын 6-ны өдөр Улаанбаатар хотноо зохион байгуулахаар ажиллаж байна.

Өнөөдөр хэдийгээр хүн төрөлхтний нийгмийн хөгжил ахин дэвшиж, техник технологи, мэдээллийн хурд санаанд оромгүйгээр бидний аж амьдрал, сэтгэхүй, оршихуйд нөлөөлж байгаа боловч дэлхийн улс орнууд, үзэл бодол, шашин шүтлэг, соёл хандлагаараа талцан хуваагдаж, энэ нь нийгэмд эерэг, сөрөг үр дагаврыг Үзүүлснээр философи, хүний эрхийн шинэ шинэ асуудлыг бий болгож буй билээ. Тиймээс бид энэхүу улсын олимпиадыг жам ёсны эрх, сонголт, чөлөөт хүсэл, хариуцлагын философийн асуудал, шашин, соёлын уламжлал, улс төр, эдийн засгийн санаа бодлыг чиглүүлэн ухааны цэцийг сориход зориулж байна. Олимпиад нь оюутан залуучуудад хүний эрхийн асуудлыг философийн үҮднээс эргэцүүлэн тунгаах, үндэслэл дэвшүүлэх, илтгэх, дүгнэлт гаргах чадварыг нэмэгдүүлэх, асуудалд хүний эрхийн мэдрэмжтэй хандах, бие даан шийдвэр гаргахад суралцахад туслах зорилготой юм. Түүнчлэн “Хэрэглээний ёс зүйн асуудлууд” эрдэм шинжилгээний хурлыг МУИС-ийн 75 жилийн ой болон дэлхийн философийн өдрийг тохиолдуулан энэ оны 11 дүгээр сарын 23-ны өдөр зохион байгуулахаар ажиллаж байна.

XXI зуунд боловсролын парадигм нь мэдлэг төвтэй боловсролоос хүмүүнлэг харилцаа төвтэй боловсролд шилжиж байна. Үүнтэй холбоотойгоор хэрэглээний ёс зүйн асуудал анхаарал татсаар байна. Хэрэглээний ёс зүй нь нийгмийн харилцааг боловсронгуй болгох нийгмийн тогтвортой хөгжлийг хангахад чухал үүрэг гүйцэтгэдэг. Манай улс дахь хэрэглээний ёс зүйн сургалт, судалгааны өнөөгийн байдалд үнэлэлт дүгнэлт өгөх, түүний үр өгөөжийг хэрхэн дээшлүүлэх вэ гэдэг асуудал мэргэжлийн багш, судлаач бидний өмнө тулгамдсан асуудал болж байна. Иймээс Монгол дахь хэрэглээний ёс зүйн сургалт, судалгааны ажлын ололт, дутагдлын талаар мэргэжлийн хүрээнд хэлэлцэж, орчин цагийн монголын болон гадаад улс орны хэрэглээний ёс зүйн сургалт, судалгааны үр дүнг толилуулах, энэ асуудлаарх цаашид анхаарах асуудал, түүнийг шийдвэрлэх арга замыг тодорхойлох зорилгоор энэХүҮ эрдэм шинжилгээний бага хурлыг зохион байгуулж байна.

Эрдэм шинжилгээний хурал нь хэрэглээний ёс зүйн тулгамдаж буй асуудлыг тодорхойлох, эрдэмтэн судлаачид, багш нарын судалгаа шинжилгээний 
ажлын хамтын ажиллагааг эрчимжүүлэх, хэрэглээний ёс зүйн сургалт, судалгааны ажлын чанар, үр өгөөжийг дээшлүүлэх, монголын нийгэм дэх ёс суртахууны доройтлыг даван туулахад тодорхой хувь нэмэр оруулах ач холбогдолтой юм. Түүнчлэн Дэлхийн философийн өдөр, Монгол Улсын Шинжлэх ухааны ажилтны өдөр, Философийн хүрээлэн үүсэн байгуулагдсаны 45 жилийн ойг тохиолдуулан хэд хэдэн ажил зохион байгуулна.

ШУА-ийн Түүхийн хүрээлэнгийн "Гүн ухаан, хууль цааз судлалын тасаг"ийг бэхжүүлэх, эрдэм шинжилгээний үйл ажиллагааг нь өргөжүүлэн идэвхжүүлэхээр 1972 оны 7 дугаар сарын 15-нд МАХНын Төв хорооны Улс төрийн товчооны 193 дугаар тогтоолын дагуу Философи, социологи, эрхийн хүрээлэн болгож, философи, социологи, төр эрхийн сектортэйгээр өргөтгөн зохион байгуулсан бөгөөд Төр, эрхийн секторын эрхлэгчээр тухайн үед Улсын Дээд Шүүхийн орлогч даргаар ажиллаж байсан Б.Содовсүрэнг томилсон байна. Доктор Б.Содовсүрэн нь тухайн чиглэлээр ажиллах мэргэжлийн боловсон хүчин тэр бүр олдохгүй дутагдаж байх үед чадварлаг баг бүрдүүлэн ажиллаж төр, эрх зүйн түүх, онол, арга зүйн асуудал, төр захиргаа, иргэн, аж ахуйн эрх зүйн тулгамдсан асуудлыг судалж, үр өгөөжийг практик амьдралд нэвтрүүлж ажиллахад чухал үүрэг гүйцэтгэсэн билээ. 2017 оны 10 дугаар сарын 20-ны өдөр Доктор Б.Содовсүрэнгийн мэндэлсний 90 жилийн ой тохиож буйтай холбогдуулан хүрээлэнгийн Эрдмийн хамт олноос холбогдох байгууллагуудтай хамтран эрдэм шинжилгээний бага хурал, хөрөг хэлэлцүүлгийг “Академич төрүүлсэн хуульч эрдэмтэн” сэдвийн дор тэмдэглэх юм. Чингэхдээ:

- Эрдэм шинжилгээний хурал, хүндэтгэлийн лекц, үзэсгэлэн, бүтээлийн болон гэрэл зургийн үзэсгэлэн ажиллах юм.

- Доктор Б.Содовсүрэнгийн хэвлэн нийтлүүлсэн нэг сэдэвт болон хамтын бүтээл, эрдэм шинжилгээний өгүүлэл, илтгэлийн эмхтгэл болон түүнтэй хамт

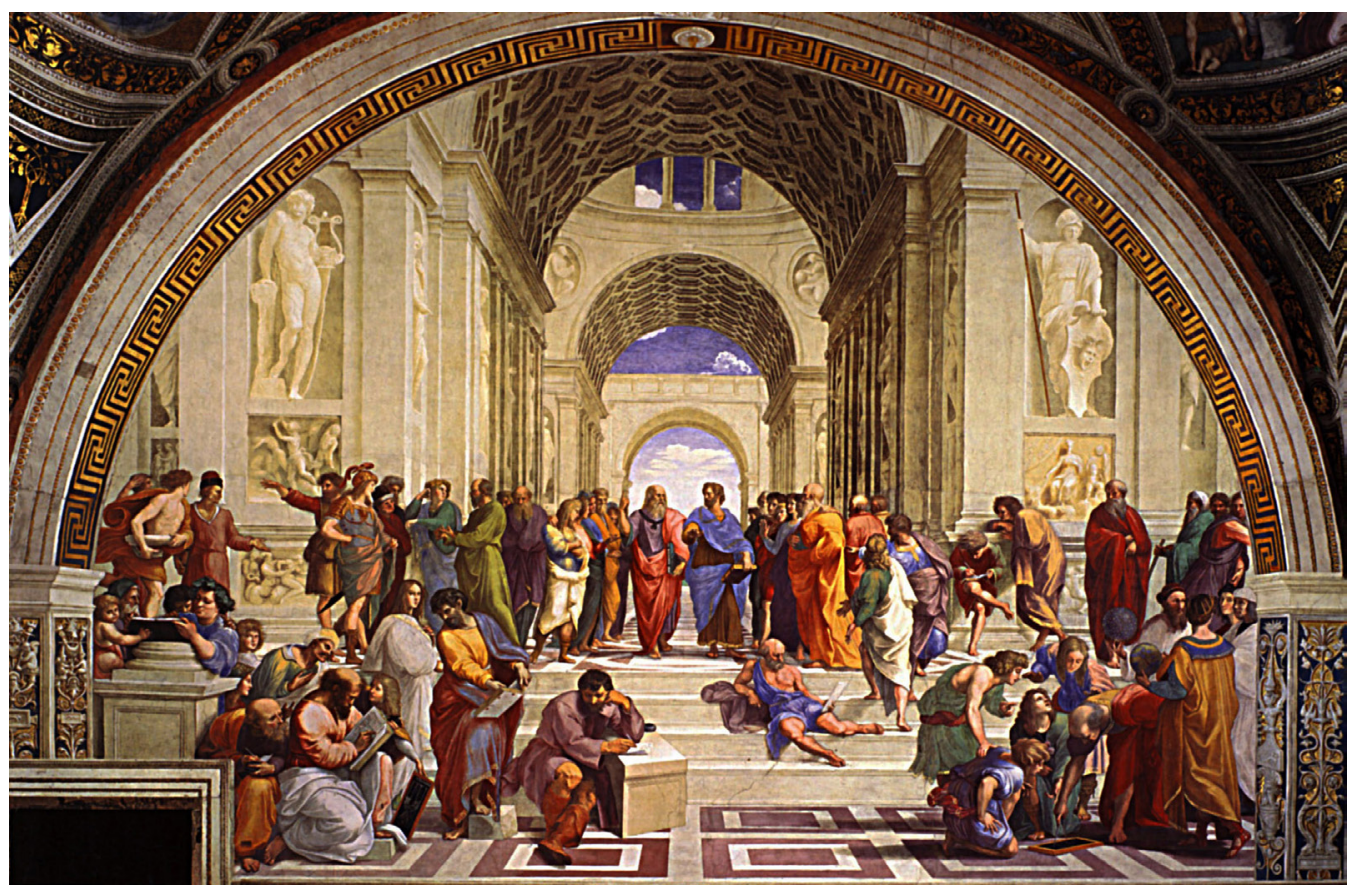


ажиллаж байсан эрдэмтэд, судлаач, шавь нарын дурсамж, эрдэм шинжилгээний бага хуралд илтгэл тавьж хэлэлцүүлсэн илтгэгчдийн илтгэлийн хамт эмхэтгэн хэвлүүлж, нийтийн хүртээл болгоно.

Түүнчлэн Хэнтий аймгийн Иргэдийн төлөөлөгчдийн хурлын 2017 оны 4 дүгээр сарын 17-ны өдрийн тогтоолоор Дорнын гүн ухаантан Занын Агваанбалдангийн мэндэлсний 220 жилийн ойг тэмдэглэхээр шийдвэрлэсэн байна. Дорнын гүн ухаантан, монголын их сэтгэгч, тунгалаг цорж Занын Агваанбалдангийн мэндэлсний 220 жилийн ойг тохиолдуулан монголын гүн ухааны сэтгэлгээний түүх, уламжлалыг орчин үеийн шинжлэх ухааны үүднээс түүхчлэн судлах, судлан боловсруулах онол, танин мэдэхүйн өндөр ач холбогдолтой юм.

Уг арга хэмжээний үеэр Монгол Улсад монголын гүн ухаан, монголын буддын соёл, буддын шашин-соёлын зохих уламжлалыг буй болгож, буддын гүн ухаантнуудын зохиолыг орчуулах, хэвлэх, тайлбар зохиох, буддын судлалын хөгжлийг дэмжих, түүнд дорвитой хувь нэмэр оруулсан эрдэмтэн судлаачдын шилдэг бүтээлийг үнэлж урамшуулах юм. Монголын гүн ухаан, философи-сэтгэлгээний шилдэг бүтээл, судлаачдад “3.Агваанбалдангийн нэрэмжит шагнал"-ыг 5 жилд нэг удаа монголын гүн ухаан, гүн ухаантан 3.Агваанбалдангийн гүн ухааны сэтгэлгээ, буддын философиор судалгаа хийж буй эрдэмтэн, судлаачдад олгохоор тогтсон нь уг арга хэмжээний нэг гол онцлог хэмээн үзэж болно.

ЭнэхуУ арга хэмжээг ШУА-ийн Философийн хүрээлэн, Хэнтий аймгийн Засаг даргын тамгын газар, Иргэдийн төлөөлөгчдийн хурал, тус аймгийн Галшар сумын Засаг даргын тамгын газар, Иргэдийн төлөөлөгчдийн хурал болон Гандантэгчинлэн хийдийн Эрдэм соёлын хүрээлэн хамтран зохион байгуулахаар ажиллаж байна.

О.Хатанболд, доктор (Ph.D) 